\title{
Aldosterone alters the chromatin structure of the murine endothelin-1 gene
}

\author{
Amanda K. Welch ${ }^{1,2}$, I. Jeanette Lynch ${ }^{1,3}$, Michelle L. Gumz ${ }^{3,4}$, Brian D. Cain ${ }^{4}$, and Charles \\ S. Wingo ${ }^{1,3}$ \\ ${ }^{1}$ North Florida/South Georgia VA Health System, Gainesville FL 32608 \\ ${ }^{2}$ Department of Physiology, University of Florida, Gainesville FL 32610 \\ ${ }^{3}$ Department of Medicine, Division of Nephrology, Hypertension, and Renal Transplantation, \\ University of Florida, Gainesville FL 32610 \\ ${ }^{4}$ Department of Biochemistry and Molecular Biology, University of Florida, Gainesville FL 32610
}

\section{Abstract}

Aldosterone increases sodium reabsorption in the renal collecting duct and systemic blood pressure. Paradoxically, aldosterone also induces transcription of the endothelin-1 (Edn1) gene to increase protein (ET-1) levels, which inhibits sodium reabsorption.

\begin{abstract}
Aims-Here we investigated changes in the chromatin structure of the Edn1 gene of collecting duct cell lines in response to aldosterone treatment. The Edn1 gene has a CpG island that encompasses the transcription start site and four sites in the 5' regulatory region previously linked to transcriptional regulation.
\end{abstract}

\begin{abstract}
Materials and methods-The chromatin structure of the Edn1 gene was investigated using a quantitative PCR-based DNaseI hypersensitivity assay in murine hepatocyte (AML12), renal cortical collecting duct $\left(\mathrm{mpkCD}_{\mathrm{C} 14}\right)$, outer medullary collecting duct1 (OMCD1), and inner medullary collecting duct-3 (IMCD-3) cell lines.
\end{abstract}

\begin{abstract}
Key findings-The CpG island was uniformly accessible. One calcium-responsive NFAT element remained at low chromatin accessibility in all cell lines under all conditions tested. However, the second calcium responsive NFAT element located at -1563 bp upstream became markedly more accessible in IMCD-3 cells exposed to aldosterone. Importantly, one established aldosterone hormone response element HRE at -671 bp relative to the transcription start site was highly accessible, and another HRE (- $551 \mathrm{bp}$ ) became more accessible in aldosterone-treated IMCD-3 and OMCD1 cells.
\end{abstract}

\footnotetext{
To whom correspondence should be addressed: Charles S. Wingo, Department of Medicine, Division of Nephrology, Hypertension, and Renal Transplantation, University of Florida, PO Box 100224, 1600 SW Archer Rd, Gainesville FL 32610, Tel: (352) 376-1611 x4152, cswingo@ufl.edu.

Publisher's Disclaimer: This is a PDF file of an unedited manuscript that has been accepted for publication. As a service to our customers we are providing this early version of the manuscript. The manuscript will undergo copyediting, typesetting, and review of the resulting proof before it is published in its final citable form. Please note that during the production process errors may be discovered which could affect the content, and all legal disclaimers that apply to the journal pertain.
} 
Significance-The evidence supports a model in which aldosterone activation of the mineralocorticoid receptor (MR) results in the MR-hormone complex binding at HRE at -671 bp to open chromatin structure around other regulatory elements in the Edn1 gene.

\section{Keywords}

aldosterone; chromatin structure; chromatin; epigenetics; kidney

\section{INTRODUCTION}

Endothelin-1 peptide (ET-1) has a highly complex role in renal function (Ahn et al. , 2004, Baylis, 1999, Ge et al. , 2005, Ge et al. , 2006, Inscho et al. , 2005, Khanna et al. , 2005, Kohan, 2006, Kohan et al. , 2011, Lynch et al. , 2013). Previously, our laboratory investigated the early transcriptional response of aldosterone in mIMCD-3 cells at one hour by microarray analysis (Gumz et al. , 2003). This approach identified several novel aldosterone stimulated genes, including the endothelin-1 gene (Edn1). Aldosterone also increased $E d n 1$ gene expression in murine collecting duct cells, and more importantly, the levels of the ET-1 peptide in the inner medulla of rats and Edn1 gene expression in murine collecting duct cells (Stow et al. , 2009). This presented an interesting paradox because ET-1 works to promote sodium excretion, while aldosterone acts in these same cells to facilitate sodium reabsorption. Later work in other laboratories established the importance of ET-1 in the kidney to regulate blood pressure and sodium reabsorption. Mice with a renal collecting duct, principal cell specific knockout of the Edn1 gene exhibited a salt-sensitive hypertension phenotype (Ahn et al., 2004).

The murine Edn1 transcription unit is $6720 \mathrm{bp}$, spanning five exons, and the resulting processed mRNA is 2344 bases long. Translation yields the 202 amino acid peptide preproendothelin-1(Maemura et al., 1996) . The protein is further processed to the final 21 amino acid peptide, ET-1. Production of ET-1 is largely regulated on the transcriptional level. The promoter region of the $E d n 1$ gene is highly conserved amongst mammalian species (for review see Stow et al., 2011 (Stow et al. , 2011)). The promoter proximal area of the gene including the transcription start site is within a $\mathrm{CpG}$ island (Figure 1) (Vallender and Lahn, 2006).

A variety of stimuli positively regulate the $E d n 1$ gene in a tissue- and cell-specific manner. In the kidney, ET-1 is known to be regulated by calcium, aldosterone, and in a timedependent manner by Per1. In the upstream distal region of the Edn1 promoter there are two calcium/calmodulin regulatory elements, nuclear factor of activated T-cells (NFATs), that appear to be important for regulation of the gene in the kidney (Strait et al. , 2010). The more distal NFAT element was found to bind NFATc3-4 and the proximal NFAT element preferentially bound NFATc1-2. Additionally, at -671 to $-690 \mathrm{bp}$ and -551 to -572 bp there are two hormone response elements (HREs) (Figure 1). These elements are recognized by the mineralocorticoid receptor (MR) and/or the glucocorticoid receptor (GR), as the two receptors share overlapping DNA targets (Stow et al., 2009, Stow et al. , 2012). Both hormone receptors were activated to bind the Edn1 HREs in an aldosterone concentrationand time-dependent manner. 
Epigenetic regulation of genes is important in a variety of physiological and pathological events. For example, epigenetic regulation is responsible for the switch from fetal to adult hemoglobin in humans, which is essential for normal development (Liang et al. , 2008). Very little is known about the epigenetic regulation of the Edn1 gene, and no consideration has been given about how the chromatin structure of Edn1 changes in response to stimuli. Here we systematically quantify the chromatin accessibility of the 5 ' regulatory region and $\mathrm{CpG}$ island of the murine Edn1 gene in liver, renal cortical collecting duct, renal outer medullary collecting duct, and inner medullary collecting duct cell lines. The results indicate that exposure to aldosterone alters the chromatin structure of the murine $E d n 1$ gene in a tissueand cell-specific manner.

\section{MATERIALS AND METHODS}

\subsection{Materials}

All materials for cell culture were obtained from Genesee Scientific, Inc. and Invitrogen. Chemicals were obtained from Fisher Scientific or Sigma-Aldrich unless otherwise specified.

\subsection{Cell Culture and Aldosterone Treatment}

The mIMCD-3 and AML12 cells were bought from ATCC. The mpkCCD ${ }_{\mathrm{c} 14}$ cells were a kind gift from Dr. Alain Vandewalle (Bens et al. , 1999). The OMCD1 cells were a kind gift from Dr. Thomas Dubose (Guntupalli et al. , 1997). The mIMCD-3, OMCD1, and mpkCCD $_{\mathrm{c} 14}$ cells were maintained in Dulbecco's Modified Eagle Medium/F12 (DMEM/ F12) supplemented with $10 \%$ fetal bovine serum and $50 \mu \mathrm{g} / \mathrm{mL}$ gentamicin. The AML12 cells were cultured in DMEM supplemented with $10 \%$ heat-inactivated fetal bovine serum, $0.1 \mu \mathrm{M}$ dexamethasone, $0.877 \mu \mathrm{M}$ insulin, $5 \mathrm{ng} / \mathrm{mL}$ sodium selenite, $5 \mu \mathrm{g} / \mathrm{mL}$ apo-transferrin (human), and $100 \mathrm{U} / \mathrm{mL}$ penicillin-streptomycin. Cells were plated in 48-well plates and grown until 1 day past confluency. The medium was then changed to DMEM/F12 without phenol red supplemented with $10 \%$ steroid hormone-depleted fetal bovine serum for the mIMCD-3, OMCD1, and mpkCCD $\mathrm{c}_{14}$ cells. For the AML12 cells, medium was changed to DMEM/F12 without phenol red supplemented with $10 \%$ steroid hormone-depleted fetal bovine serum, $0.877 \mu \mathrm{M}$ insulin, $5 \mathrm{ng} / \mathrm{mL}$ sodium selenite, $5 \mu \mathrm{g} / \mathrm{mL}$ apo-transferrin (human) for 24 hours. Then, cells were treated with vehicle (100\% ethanol), $100 \mathrm{nM}$, or $1 \mu \mathrm{M}$ aldosterone for an additional 24 hours.

\subsection{RNA Isolation and TaqMan Realtime PCR assays}

Total RNA was isolated using TRIzol (Invitrogen) according to the manufacturer's instructions. Isolated RNA (10 $\mu \mathrm{g})$ was treated with the DNA-free DNA removal kit (Ambion) according to the manufacturer's instructions to eliminate genomic DNA. $2 \mu \mathrm{g}$ of the DNaseI-treated RNA served as a template for reverse transcription using High Capacity cDNA Reverse Transcription Kit (Applied Biosystems). cDNA generated (20 ng) was used as a template for TaqMan Realtime $\mathrm{qPCR}$ assays. Cycle threshold values $\left(\mathrm{C}_{\mathrm{t}}\right)$ were normalized against $\beta$-actin and were analyzed using the $\Delta \Delta \mathrm{C}_{\mathrm{t}}$ method (Livak and Schmittgen, 2001). Primer/Probe sets were purchased from Invitrogen: $S g k 1$ 
(Mm00441380_m1), Actb (Mm00607939_s1), Scnn1a(Mm00803386_m1). Results were analyzed using an unpaired Student's t-test (Microsoft Excel).

\subsection{Heterogeneous Nuclear RNA Assay}

Levels of pre-slicing $E d n 1$ hnRNA were measured using primers that amplified a region between exon 4 and intron 4 (F-5'GAAGTGTATCTATCAGCAGCTGG; R-5'AGACCATGACGACTCTATTACTGG), as described by Stow et al (Stow et al., 2009). Each qPCR contained $32 \mathrm{ng}$ cDNA, $500 \mathrm{nM}$ of each primer, and $10 \mu \mathrm{L}$ iTaq Universal SYBR Green Supermix (BioRad). Reaction conditions were as follows: initial denaturation of a hold at $95^{\circ} \mathrm{C}$ for 30 seconds; the amplification step was for 40 cycles: $95^{\circ} \mathrm{C}$ for 15 seconds, $60^{\circ} \mathrm{C} 30$ seconds, plate read; the melting curve was conducted from $65^{\circ} \mathrm{C}$ to $95^{\circ} \mathrm{C}$ at $0.5^{\circ} \mathrm{C}$ increments for 2 seconds/step. All hnRNA measurements were normalized to Gapdh (F- 5' GAAGCCCATCACCATCTTCC 3'; R-5'TGATGATCCTTTTGGCTCC 3'). Melting curves were used to verify primer specificity and agarose gel electrophoresis was used to verify product size. Results were analyzed using an unpaired Student's t-test (Microsoft Excel).

\subsection{Chromatin Accessibility Assays}

The assays were conducted using the EpiQ Chromatin Accessibility Kit (BioRad), which combines in situ chromatin digestion with qPCR to determine chromatin accessibility. Briefly, medium was aspirated from cells grown in a 48 well plate following incubation with vehicle or aldosterone. Cells were digested using DNaseI using conditions empirically optimized for each cell line. All cells were digested with $0.08 \mathrm{U} / \mu \mathrm{L}$ DNaseI (final concentration) in chromatin digestion buffer at $37^{\circ} \mathrm{C}$ for either 30 minutes (mIMCD-3, OMCD1), 15 minutes (AML12), or 10 minutes $\left(\mathrm{mpkCD}_{\mathrm{C} 14}\right)$. Controls for all cells were performed under the same conditions without DNaseI. The digestion was stopped and genomic DNA was isolated using spin columns. To ensure that all experiments met certain quality controls, qPCR was performed using SYBR green with the following primers against the rhodopsin (RHO) gene and glyceraldehyde 3-phosphate dehydrogenase (GAPDH) (Table 1). The RHO gene served as a negative control for chromatin accessibility because it is not expressed in the kidney or liver. Therefore, the chromatin is closed and not accessible to the DNaseI. GAPDH served as a positive control because it is constitutively active and readily accessible to DNaseI.

Assays were performed in triplicate in three independent trials using three separate passages of cells on three separate days. All trials were vetted for experimental error. To control for the possible over-digestion, only those samples that had a difference in $\mathrm{C}_{\mathrm{t}}$ values between the digested and undigested samples of RHO was less than 1.5 were used in further experiments. Similarly, to control for endogenous nuclease digestion, only samples that had difference in $\mathrm{C}_{\mathrm{t}}$ values of less than 1.5 between the undigested RHO and GAPDH genes were studied. The efficiency of amplification was used for calculating the percent accessibility (Equation 1). To assure that the assay worked, the accessibility of the digested GAPDH gene was greater than or equal to $95 \%$. Chromatin accessibility was calculated using the following equation: 


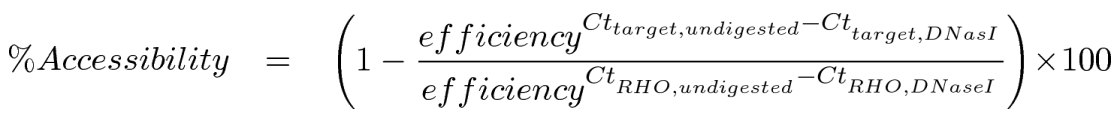

Equation 1

Equation 1 measures the percent accessibility compared to the RHO gene. qPCR measures, by proxy, the amount of intact template in a reaction, in this case the target regions. The denominator in Equation 1 will be small (approaching 1) because the $\Delta \mathrm{Ct}$ value of RHO digested and undigested should approach zero. The numerator will give the fold change of the target undigested and digested. The ratio yields the relative amount of the region of interest after digestion normalized to RHO. This ratio is converted to percent accessibility by subtracting the ratio from 1 and multiplying that by 100 . Accessibility can be divided into four general categories: $\geq 95 \%$ is considered highly accessible; $65-94 \%$ is accessible; 20 $65 \%$ is lowly accessible; and $0-20 \%$ is inaccessible. Primers against target regions were designed using primer3 (http://primer3.ut.ee). Primers for the target regions are listed in Table 1. For each primer set the melting temperature $(\mathrm{Tm})$ was empirically determined using a temperature gradient for the annealing step from $63-72{ }^{\circ} \mathrm{C}$ (Table 1 ). The Tm selected only showed one amplification peak and no non-specific amplification in the no template control reaction. Following Tm determination, the efficiency of amplification for each primer pair was determined using a standard curve for template DNA of 0-1000 pg/ $\mu \mathrm{L}$. Results were analyzed using an unpaired Student's t-test (Microsoft Excel).

\section{RESULTS}

\subsection{Aldosterone Induces Transcription of the Edn1 Gene}

The mpkCCD $\mathrm{C1}_{14}$, OMCD1, and IMCD-3 cell lines are derived from the principal cells of the murine renal cortical, outer medullary, and inner medullary collecting ducts, respectively. All three collecting duct derived cell lines are known to be responsive to aldosterone, and transcription and mRNA levels of the Edn1 gene increased in response to aldosterone (Stow et al., 2009). An important negative control was provided by murine liver AML12 cells that express many aldosterone responsive genes, including Edn1. Both alpha $\mathrm{ENaC}$ (Scnn1a) and Sgk-1 (Sgk-1) mRNA levels were upregulated in AML12 cells in response to aldosterone by 2 -fold and almost 4-fold, respectively (Figure 2A). However, absolutely no change was observed in Edn1 mRNA levels (Average $\mathrm{Ct}=28.2$ ).

To confirm that aldosterone treatment increased $E d n 1$ transcription and mRNA levels, AML12, mpkCCD $\mathrm{C} 14_{4}, \mathrm{OMCD} 1$, and IMCD-3 cells were treated with vehicle or $100 \mathrm{nM}$ aldosterone for 24 hours, and transcription was determined by assaying hnRNA and steadystate mRNA levels. Previous work in our laboratory has confirmed the presence the mineralocorticoid and glucocorticoid receptor via western blot in the renal cell lines (Stow et al., 2009).The relatively high concentration of aldosterone ensured a maximum response in all cells within cultures. As expected, the AML12 cells showed no change in Edn1 hnRNA or mRNA from vehicle to aldosterone treated conditions (Figures 2B, C). Clearly, Edn1 was not responsive to aldosterone in liver cells. However, greater than 3-fold increases in Edn1 hnRNA levels were induced by aldosterone in all three renal collecting duct cell lines 
(Figure 2B), confirming induction of transcriptional activity. Increases in steady-state Edn1 mRNA levels in the mpkCCD $\mathrm{C} 14_{4}$ and IMCD-3 cell lines were comparable to previously reported levels for these cells acutely treated with aldosterone (Figure 2C).

\subsection{Chromatin Accessibility of Edn1 Regulatory Elements}

The CpG island in the murine Edn1 gene extends approximately from -500bp to $159 \mathrm{bp}$, covering the transcription start site into the first intron (Vallender and Lahn, 2006). Four primer pairs were designed to allow study of the entire $\mathrm{CpG}$ island (Table 1). The primers were designed to have minimal overlap between amplicons (Figure 1). Following in situ DNaseI chromatin digestion genomic DNA was isolated, and qPCR was performed using primers designed to examine the accessibility of the $\mathrm{CpG}$ island (Figure 3). The CpG1 amplicon specifically covering the $E d n 1$ promoter proximal 5' regulatory region consistently was the most accessible region, scoring 93\% accessibility in all four cell lines. Indeed, all four amplicons showed high DNaseI accessibility. There were no apparent aldosteronedependent changes in chromatin structure. The evidence indicates that the promoter region of the Edn1 gene remains wide open for assembly of a transcription initiation complex in collecting duct cells.

A more interesting result was obtained by examining the distal sites in the 5' regulatory region of the Edn1 gene (Figure 4). Four regions that are known to be important in the transcriptional regulation of the gene in renal collecting duct cells were chosen for study (Stow et al., 2009, Stow et al., 2012, Strait et al., 2010). These were the two HREs located at $-551 \mathrm{bp}$ and $-671 \mathrm{bp}$ and the two putative nuclear factor of activated T-cells (NFAT) elements located at approximately $-1263 \mathrm{bp}$ and -1563 bp upstream of the transcription start site in the murine gene (Strait et al., 2010). Primers were carefully designed to avoid inclusion of both HREs in the same amplicon to unambiguously discern differences in chromatin structure between the two elements (Figure 1). The sequence of the HRE at $-551 \mathrm{bp}$ overlaps with a non-cannonical Ebox element involved in the time-dependent regulation of the gene, so it was not technically possible to isolate those two elements. Primer sequences for all amplicons are shown in Table 1.

The distal NFAT element ( -1563 bp in the murine gene, Figure 1 far left) was lowly accessible in all cell lines under vehicle treated conditions (Figure 4A). When exposed to aldosterone, there is no significant change in accessibility in the AML12, OMCD1, and mpkCCD ${ }_{\mathrm{C} 14}$ cells. However, the IMCD-3 cells showed a dramatic and reproducible increase in accessibility upon aldosterone treatment. No change in accessibility was observed with the proximal NFAT element ( $-1263 \mathrm{bp}$ in the murine gene) (Figure 4B). The high affinity MR site HRE at -671 bp displayed high accessibility under all conditions tested and in all cell lines (Figure $4 \mathrm{C}$ ). Accessibility ranged from $\geq 80 \%$ under vehicle conditions to $\geq 86 \%$ under aldosterone-treated conditions on average across all cell lines. HRE at $-671 \mathrm{bp}$ is apparently maintained in an open chromatin state even in the absence of hormone receptor binding.

The HRE at $-551 \mathrm{bp}$ was originally identified as the possible low affinity MR binding site (Stow et al., 2009). The IMCD-3 and OMCD1 cell lines derived from the distal regions of the collecting duct showed clear evidence of increased accessibility when exposed to 
aldosterone (Figure 4D). The most distal segment of the collecting duct represented by the IMCD-3 cell line showed the greatest increase in accessibility. Although the mpkCCD ${ }_{\mathrm{C} 14}$ and AML12 cell lines showed no aldosterone-dependent changes in accessibility, both already had very high accessibility in the absence of hormone.

\section{DISCUSSION}

Here we provide the first systematic analysis of the chromatin DNaseI accessibility of the Edn1 gene in murine renal cortical collecting duct, outer medullary collecting duct, inner medullary collecting duct, and hepatocyte cell lines. The accessibility of the chromatin structure of the 5' regulatory region and the $\mathrm{CpG}$ island of the Edn1 gene was determined in the presence and absence of aldosterone-dependent induction of the gene. The murine hepatocyte cell line, AML12, exhibits the greatest accessibility over all regions and conditions tested, but provided no evidence of aldosterone action on ET-1 expression. A similar pattern was found with the cortical collecting duct cell line, $\mathrm{mpkCD}_{\mathrm{C} 14}$. In contrast, medullary collecting duct cell lines, OMCD1 and mIMCD-3, were somewhat less accessible in the absence of hormone, but the chromatin structure became more open in response to aldosterone. This result suggests that the chromatin structure of the Edn1 gene is substantially altered as part of the mechanism of induction by aldosterone.

The murine hepatocyte AML12 cell line shows no aldosterone-dependent changes in ET-1 production or chromatin accessibility in any of the regions of the Edn1 gene. This is probably because accessibility is already very high, so there can be very little increase in accessibility. It should be noted that under non-pathological conditions the ET-1 protein is expressed at low levels in hepatocytes. Indeed, until 2000 it was thought that hepatocytes did not produce any ET-1 and were only involved in the metabolism of the protein (Kuddus et al. , 2000). This cell line does show responsiveness to aldosterone treatment for other wellknown aldosterone early response genes, $S g k-1$ and $S c n n 1 a$ (Figure 2A). While the induction of $S g k l \mathrm{mRNA}$ is logical, as it has multiple functions aside from promoting sodium transport, initially the induction of Scnn 1a mRNA was puzzling. Scnn1a encodes the alpha subunit of the epithelial sodium channel $(\mathrm{ENaC})$, which is the rate-limiting subunit for the formation of the channel, and is one of the principal channels for sodium transport in the lungs and the renal collecting duct. However, recent evidence suggests that alpha subunit of $\mathrm{ENaC}$ may also be expressed in hepatocytes under hypertonic conditions and might be responsible for the regulatory volume increase (RVI) seen in response to these conditions (Bondarava et al., 2009, Wehner et al. , 2000).

The $\mathrm{CpG}$ island was open and accessible in all cell lines and conditions tested. This accessibility was expected because the $\mathrm{CpG}$ island lies over the transcription start site (Figure 1) and the Edn1 gene is expressed under basal conditions in all cell lines. The high accessibility of the $\mathrm{CpG}$ island also served as a positive control for the assay.

The 5' regulatory region yielded more interesting results. The largest changes in chromatin accessibility occurred in the inner medullary collecting duct derived cell line, mIMCD-3. Thus, it appears that the mIMCD-3 cell line has the largest dynamic range for epigenetic regulation of the Edn1 gene. The inner medulla of the kidney has the highest expression of 
ET-1 protein levels in the body. Interestingly, the NFAT element located at $-1563 \mathrm{bp}$, but not the more proximal element at $-1263 \mathrm{bp}$, showed an increased accessibility upon addition of aldosterone. It should be noted that both elements are moderately accessible even under basal conditions. This corroborates the results from Strait et al that demonstrated that these elements were important for $E d n 1$ gene transcription in the rat inner medulla. Interestingly, the IMCD-3 cells had a lower accessibility under vehicle treated conditions than the other cell lines, but the difference between cell lines was abolished upon aldosterone treatment. The more proximal HRE at -551 bp showed an increase in accessibility upon addition of aldosterone in both the mIMCD-3 and OMCD1 cell lines. This may reflect a conformational change or bend in the DNA that allows for greater accessibility for the transcriptional machinery. However, this working model will require further study.

\section{CONCLUSIONS}

Each cell line exhibits a different range in aldosterone-induced chromatin accessibility changes. This may reflect the dynamic range for gene expression of the $E d n 1$ gene in each of the cell lines. It is unknown if the mineralocorticoid receptor is involved in chromatin remodeling. However, the closely-related glucocorticoid receptor has been shown to recruit the SWI/SNF chromatin remodeling complex to alter chromatin structure (King et al. , 2012). It stands to reason that the mineralocorticoid receptor could alter chromatin structure in a similar manner. Moreover, it should be noted that work in our laboratory demonstrated that both MR and GR can bind the HREs located in the 5' regulatory region of the Edn1 gene and SRC-1 was recruited in an aldosterone-dependent manner (Stow et al., 2009, Stow et al., 2012). Taken together, our working model for the distal collecting duct mIMCD-3 and OMCD1 cell lines shows that under basal conditions the HRE at $-671 \mathrm{bp}$ and the transcription start site are accessible (Figure 5). Upon exposure to aldosterone, the mineralocorticoid receptor readily binds to the highly accessible HRE site at $-671 \mathrm{bp}$. This binding causes a conformational change to increase accessibility to the distal NFAT site at $-1563 \mathrm{bp}$ in the mIMCD-3 cell line. It also results in a conformational change or perhaps a bend in the DNA to increase accessibility around the more proximal HRE at $-551 \mathrm{bp}$ allowing for recruitment of the transcription preinitiation complex to the transcription start site.

\section{ACKNOWLEDGEMENTS}

This work was supported by NIH grant NDDK R01 DK82680 to CSW and BDC and NIH postdoctoral fellowship 2T32 HL083810 to AKW.

\section{REFERENCES}

Ahn D, Ge Y, Stricklett PK, Gill P, Taylor D, Hughes AK, et al. Collecting duct-specific knockout of endothelin-1 causes hypertension and sodium retention. J Clin Invest. 2004; 114:504-11. [PubMed: 15314687]

Baylis C. Acute interactions between endothelin and nitric oxide in the control of renal haemodynamics. Clin Exp Pharmacol Physiol. 1999; 26:253-7. [PubMed: 10081623]

Bens M, Vallet V, Cluzeaud F, Pascual-Letallec L, Kahn A, Rafestin-Oblin ME, et al. Corticosteroiddependent sodium transport in a novel immortalized mouse collecting duct principal cell line. J Am Soc Nephrol. 1999; 10:923-34. [PubMed: 10232677] 
Bondarava M, Li T, Endl E, Wehner F. alpha-ENaC is a functional element of the hypertonicityinduced cation channel in HepG2 cells and it mediates proliferation. Pflugers Arch. 2009; 458:67587. [PubMed: 19241091]

Ge Y, Ahn D, Stricklett PK, Hughes AK, Yanagisawa M, Verbalis JG, et al. Collecting duct-specific knockout of endothelin-1 alters vasopressin regulation of urine osmolality. Am J Physiol Renal Physiol. 2005; 288:F912-20. [PubMed: 15632412]

Ge Y, Bagnall A, Stricklett PK, Strait K, Webb DJ, Kotelevtsev Y, et al. Collecting duct-specific knockout of the endothelin B receptor causes hypertension and sodium retention. Am J Physiol Renal Physiol. 2006; 291:F1274-80. [PubMed: 16868309]

Gumz ML, Popp MP, Wingo CS, Cain BD. Early transcriptional effects of aldosterone in a mouse inner medullary collecting duct cell line. Am J Physiol Renal Physiol. 2003; 285:F664-73. [PubMed: 12770840]

Guntupalli J, Onuigbo M, Wall S, Alpern RJ, DuBose TD Jr. Adaptation to low-K+ media increases $\mathrm{H}(+)-\mathrm{K}(+)$-ATPase but not $\mathrm{H}(+)$-ATPase-mediated pHi recovery in OMCD1 cells. Am J Physiol. 1997; 273:C558-71. [PubMed: 9277353]

Inscho EW, Imig JD, Cook AK, Pollock DM. ETA and ETB receptors differentially modulate afferent and efferent arteriolar responses to endothelin. Br J Pharmacol. 2005; 146:1019-26. [PubMed: 16231007]

Khanna A, Simoni J, Wesson DE. Endothelin-induced increased aldosterone activity mediates augmented distal nephron acidification as a result of dietary protein. J Am Soc Nephrol. 2005; 16:1929-35. [PubMed: 15872074]

King HA, Trotter KW, Archer TK. Chromatin remodeling during glucocorticoid receptor regulated transactivation. Biochim Biophys Acta. 2012; 1819:716-26. [PubMed: 22425674]

Kohan DE. The renal medullary endothelin system in control of sodium and water excretion and systemic blood pressure. Curr Opin Nephrol Hypertens. 2006; 15:34-40. [PubMed: 16340664]

Kohan DE, Rossi NF, Inscho EW, Pollock DM. Regulation of blood pressure and salt homeostasis by endothelin. Physiol Rev. 2011; 91:1-77. [PubMed: 21248162]

Kuddus RH, Nalesnik MA, Subbotin VM, Rao AS, Gandhi CR. Enhanced synthesis and reduced metabolism of endothelin-1 (ET-1) by hepatocytes--an important mechanism of increased endogenous levels of ET-1 in liver cirrhosis. J Hepatol. 2000; 33:725-32. [PubMed: 11097479]

Liang S, Moghimi B, Yang TP, Strouboulis J, Bungert J. Locus control region mediated regulation of adult beta-globin gene expression. J Cell Biochem. 2008; 105:9-16. [PubMed: 18500726]

Livak KJ, Schmittgen TD. Analysis of relative gene expression data using real-time quantitative PCR and the 2(-Delta Delta C(T)) Method. Methods. 2001; 25:402-8. [PubMed: 11846609]

Lynch IJ, Welch AK, Kohan DE, Cain BD, Wingo CS. Endothelin-1 inhibits sodium reabsorption by ET(A) and ET(B) receptors in the mouse cortical collecting duct. Am J Physiol Renal Physiol. 2013; 305:F568-73. [PubMed: 23698114]

Maemura K, Kurihara H, Kurihara Y, Oda H, Ishikawa T, Copeland NG, et al. Sequence analysis, chromosomal location, and developmental expression of the mouse preproendothelin-1 gene. Genomics. 1996; 31:177-84. [PubMed: 8824799]

Stow LR, Gumz ML, Lynch IJ, Greenlee MM, Rudin A, Cain BD, et al. Aldosterone modulates steroid receptor binding to the endothelin-1 gene (edn1). J Biol Chem. 2009; 284:30087-96. [PubMed: 19638349]

Stow LR, Jacobs ME, Wingo CS, Cain BD. Endothelin-1 gene regulation. Faseb j. 2011; 25:16-28. [PubMed: 20837776]

Stow LR, Voren GE, Gumz ML, Wingo CS, Cain BD. Dexamethasone stimulates endothelin-1 gene expression in renal collecting duct cells. Steroids. 2012; 77:360-6. [PubMed: 22209709]

Strait KA, Stricklett PK, Kohan RM, Kohan DE. Identification of two nuclear factor of activated Tcells (NFAT)-response elements in the 5'-upstream regulatory region of the ET-1 promoter. J Biol Chem. 2010; 285:28520-8. [PubMed: 20647310]

Vallender TW, Lahn BT. Localized methylation in the key regulator gene endothelin-1 is associated with cell type-specific transcriptional silencing. FEBS Lett. 2006; 580:4560-6. [PubMed: 16870175] 
Wehner F, Bohmer C, Heinzinger H, van den Boom F, Tinel H. The hypertonicity-induced $\mathrm{Na}(+)$ conductance of rat hepatocytes: physiological significance and molecular correlate. Cell Physiol Biochem. 2000; 10:335-40. [PubMed: 11125214] 


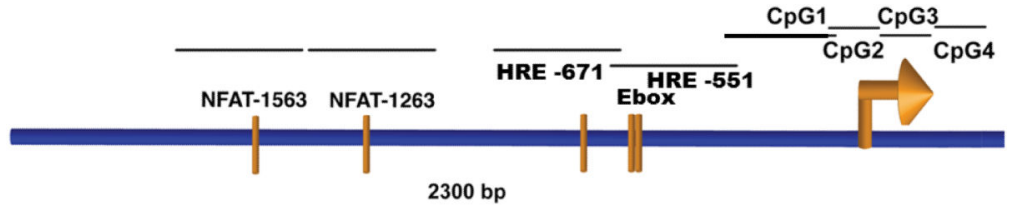

Figure 1. Regions examined for chromatin accessibility in the Edn1 gene

The $2300 \mathrm{bp}$ region that encompasses the 5' regulatory region, transcription start site, and $\mathrm{CpG}$ island is represented by the blue bar. Vertical orange bars represent the locations of the NFAT elements and HREs and are labeled above. The large arrow denotes the location of the transcription start site. The thin black horizontal lines show the region encompassed by each amplicon. The amplicons for the $\mathrm{CpG}$ island are labeled as $\mathrm{CpG} 1-4$. 

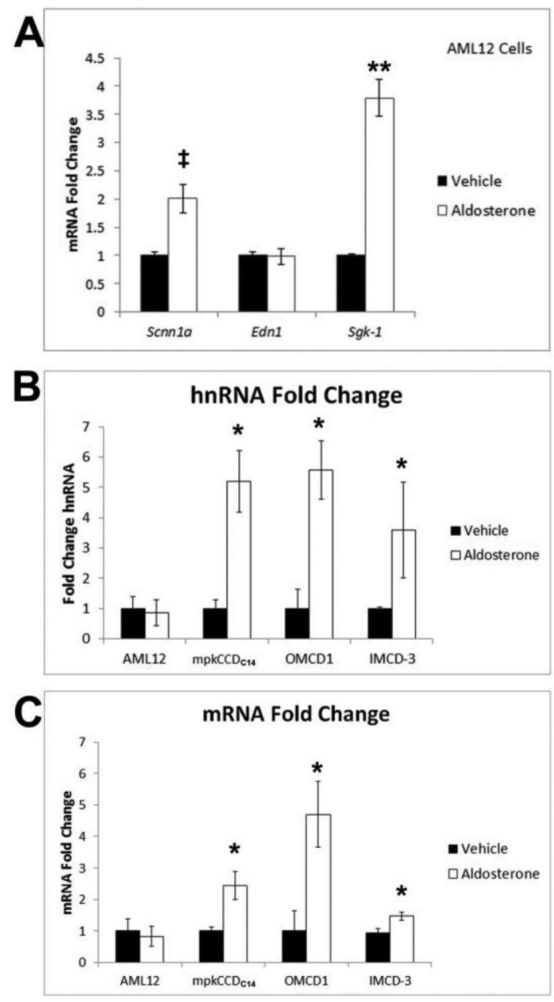

Figure 2. Aldosterone stimulates expression of the $E d n 1$ gene in murine renal cells, but not hepatocytes

(A) AML-12 cells were treated for 24 hours with either vehicle (open bars) or $1 \mu \mathrm{M}$ aldosterone (closed bars). RNA was isolated and qPCR was performed to determine the relative mRNA levels. All mRNA levels were normalized to $\beta$-actin. (n=4), (B) AML-12, IMCD-3, OMCD1, and mpkCCD ${ }_{\mathrm{C} 14}$ cells were treated with either vehicle (open bars) or $100 \mathrm{nM}$ aldosterone (closed bars) for 24 hours. Edn $1 \mathrm{hnRNA}$ was measured using qPCR as an indicator of transcription and was normalized to Gapdh hnRNA. (n=3) (C) Cells were treated as with either vehicle or $100 \mathrm{nM}$ aldosterone for 24 hours and mRNA levels were measured as in (A) $(n=3)$. Results are expressed as a relative fold change to the vehicle treated cells \pm standard error of the mean. $\ddagger, \mathrm{p}<0.01 ; *, \mathrm{p}<0.05 ; * *, \mathrm{p}<0.001$ 

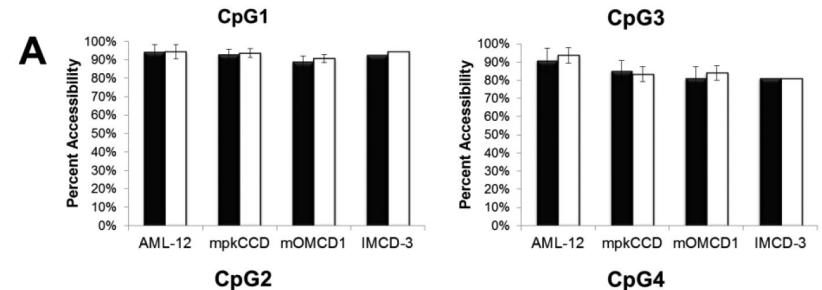

B
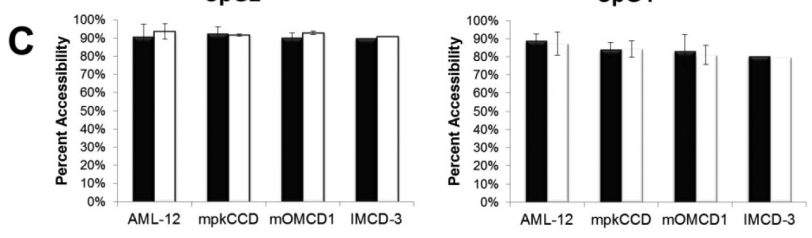

Vehicle
$\square$ Aldosterone

Figure 3. Aldosterone does not alter the chromatin structure of the CpG island in the Edn1 gene AML-12, IMCD-3, OMCD1, and mpkCCD ${ }_{\mathrm{C} 14}$ cells were treated as in Figure 3. Chromatin accessibility assays were performed, genomic DNA was isolated and qPCR was performed using primers in Table 1. Percent accessibility was calculated according to Equation 1 shown \pm standard deviation $(\mathrm{n}=3) . *{ }^{*}, \mathrm{p}<0.05$ 

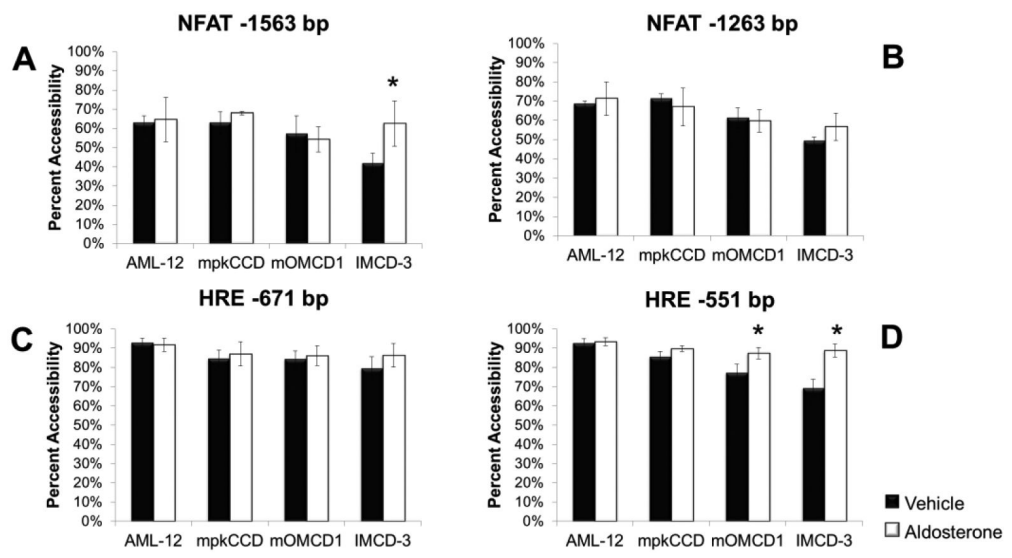

Figure 4. Aldosterone alters the chromatin structure of 5' regulatory region in IMCD-3 and OMCD1, but not AML-12 and mpkCCD ${ }_{\mathrm{C} 14}$ cells

The murine liver and renal cells were treated as in Figure 3. Chromatin accessibility assays were performed, genomic DNA was isolated and qPCR was performed using primers in Table 1. Percent accessibility was calculated according to Equation 1 shown \pm standard deviation $(\mathrm{n}=3) .{ }^{*}, \mathrm{p}<0.05$ 


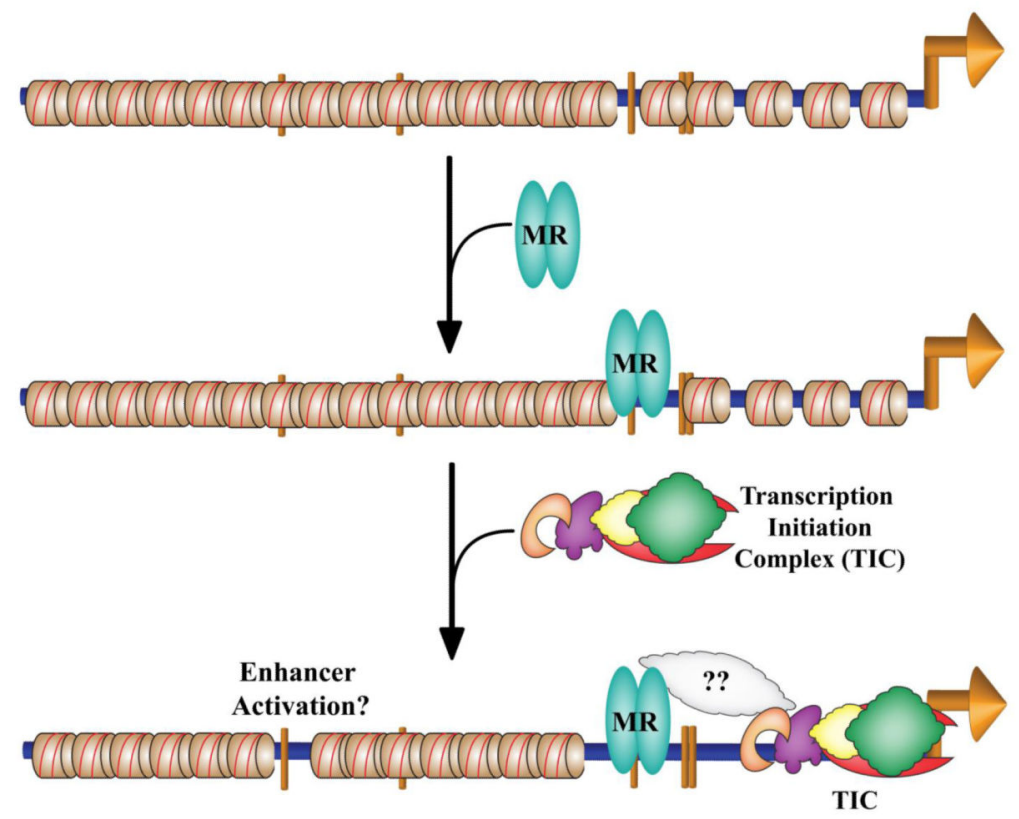

Figure 5. Model of mechanism of action for aldosterone altering chromatin structure Top, The Edn1 is active and transcribed prior to addition of aldosterone. The HRE site at $-671 \mathrm{bp}$ is open. Middle, upon addition of aldosterone the mineralocorticoid receptor (MR, teal) can bind to the HRE at $-671 \mathrm{bp}$. This may cause a conformational change in the DNA in the IMCD-3 and OMCD-1 cells. Bottom, the conformational change may allow for enhancer activation at the distal NFAT -1563 bp (denoted by Enhancer activation?). This would also allow for the transcription initiation complex (TIC, orange, purple, yellow, red, green) to bind easily to the transcription start site. Additionally, the MR may recruit other factors (shown in gray with a question mark) in the renal cells to further drive transcription. 


\section{Table 1}

Primers used for qPCR against target regions

\begin{tabular}{|c|c|c|}
\hline Target Region & Primer $\left(5^{\prime} \rightarrow 3^{\prime}\right)$ & $\mathbf{T m}$ \\
\hline RHO & $\begin{array}{l}\text { F: GGTCACTTTATAAGGGTCTGGGGG } \\
\text { R: AGTTGATGGGGAAGCCCAGCACGAT }\end{array}$ & $66.0^{\circ} \mathrm{C}$ \\
\hline GAPDH & $\begin{array}{l}\text { F: CAGCTCCCCTCCCCCTATCAGTTCG } \\
\text { R-ACCAGGGAGGGCTGCAGTCCGTATT }\end{array}$ & $66.0^{\circ} \mathrm{C}$ \\
\hline CpG1 & $\begin{array}{l}\text { F: GAGTGGGGATCGTCCCCTTGTTTGA } \\
\text { R: GTCTGACAATCCAGGGGCAGGGCTA }\end{array}$ & $70.7^{\circ} \mathrm{C}$ \\
\hline $\mathrm{CpG} 2$ & $\begin{array}{l}\text { F: GGCTGGCAGCTAGCAAAAGGGGAAG } \\
\text { R: CGGACAGTTCTCCGCCGCCTTTTTA }\end{array}$ & $63.8^{\circ} \mathrm{C}$ \\
\hline CpG3 & $\begin{array}{l}\text { F: CGGCGGAGAACTGTCCGAGTCAGAA } \\
\text { R: CGGTTGCAAATGGAACTCAATGCAAAA }\end{array}$ & $64.5^{\circ} \mathrm{C}$ \\
\hline CpG4 & $\begin{array}{l}\text { F: CCAGACACCGTCCTCTTCGTTTTGC } \\
\text { R: TGTAAGGCACTTGCTGCTGGAGCTT }\end{array}$ & $64.5^{\circ} \mathrm{C}$ \\
\hline HRE -551 bp * & $\begin{array}{l}\text { F: GGTGGAAGGGGTGGTGGTGGAAAAG } \\
\text { R: CCAGAAGCAAAGTCACCCCATTGGA }\end{array}$ & $66.0^{\circ} \mathrm{C}$ \\
\hline HRE -671 bp & $\begin{array}{l}\text { F: GGGCACAAGAAATATTGGAGGGCGAGT } \\
\text { R: GCGGGCGGGGAACCAGATTAGTTT }\end{array}$ & $66.0^{\circ} \mathrm{C}$ \\
\hline NFAT -1263 bp & $\begin{array}{l}\text { F: TTATGGGCATTCCGGGAGCTTGTTG } \\
\text { R: GCAAACCTGCGGTCTGTGCTTGATT }\end{array}$ & $66.0^{\circ} \mathrm{C}$ \\
\hline NFAT -1563 bp & $\begin{array}{l}\text { F: GCTGCTGTGTCTCCCCTACTGAGATTC } \\
\text { R: CAACAAGCTCCCGGAATGCCCATAA }\end{array}$ & $66.0^{\circ} \mathrm{C}$ \\
\hline
\end{tabular}

